\title{
ADULT EDUCATION IN BRITAIN
}

$\mathrm{I}_{\mathrm{I}}^{\mathrm{N}}$ $\mathrm{N}$ opening a debate on adult education in the House of Lords on November 24, Lord Greenhill said there was a real increase to-day in the demand for adult education in Britain. There was, in spite of the expansion in publicly provided education, a still greater demand for advanced education, both technical, cultural and nonvocational, which we could not supply. He urged that additional accommodation, particularly in residential colleges, should be made part and parcel of Britain's normal provision of adult education. $\mathrm{He}$ was strongly supported by Lord Hill of Luton, who urged that this was one of the great tasks of to-day following the educational policies of the past twenty years. Those who sought adult education, in the sense in which the term was used by Lord Greenhill in opening the debate, must undergo a disciplined study under the guidance of a competent teacher. Television could play a part in providing this disciplined study only if other links could be created between the teacher and the taught. This would not be easy, but it would be worth while trying to take the fullest advantage of an immensely powerful medium of mass communication, without forgetting that the personality and power of the teacher were essential. Baroness Elliot of Harwood suggested that the adult education organizations should approach the question from a more modern point of view than in the past, seeking to introduce some modern ideas into the classes provided. She also suggested that the pamphlet on consumer education, recently issued by the Research Institute for Consumer Affairs, indicated exciting possibilities for the fusion of adult education and consumer education, starting from practical issues and indicating how adult education and consumer education could create the informed, self-respecting and 'concerned' persons whose influence could be so great on the mind of the society in which we lived.

Lord Chorley directed attention to three groups requiring support. First, there were the evening institutes, and the evening schools for technical education which had scarcely received the recognition they deserved; then there were the refresher courses which were becoming increasingly important in the professions and to which the Robbins Report devoted some attention; the third group was the movement for bringing up to date the adult population, as a whole, in regard to knowledge-without it the modern world was incomprehensible and the adult citizen could not play a proper part in society. Besides this there was the general cultural education mentioned by Baroness Elliot, and Lord Chorley also supported Lord Hill's remarks concerning the need for proper teaching. Lord Francis-Williams thought that, contrary to the views of the Pilkington Committee, establishment of a fourth television channel entirely devoted to education would be useful. He thought we should consider more carefully the possible development of local radio and television linked to the universities, particularly the new universities, which might join with the local education authorities and local adult education associations and possibly with some of the existing correspondence colleges for the purpose. Baroness Gaitskell also believed that this idea of a university of the air would be worth exploring and could be more effective if combined with correspondence courses. She hoped that the Government would put adult education high on its list of priorities in education.

Lord Geddes suggested that a less academic view should be taken of some of the features of adult education, that the Albemarle Report should be taken more seriously, and that adult education for the less intellectual part of the population should be linked with some of the social service activities. He suggested that more research should be encouraged into the causes of anti-social behaviour, and that in this connexion we might consider the possibility of non-military national service which would cover, under disciplined procedures, many facets of social service, such as aid to the old, hospital service, service in underdeveloped countries and agriculture.

Lord Aberdare, replying to the debate for the Government, pointed out that a good deal had already been done for adult education in Britain: grants to adult education had more than doubled in the period from $1954-55$ to $1964-65$ and the number of full-time posts had increased from 254 to 311 ; he also directed attention to what had been done in sound broadcasting in the field of adult education.

\section{MUSEUM OF LONDON BILL}

$\mathrm{N}$ moving the second reading of the Museum of London Bill in the House of Lords on November 26, Lord Champion explained that the London Museum originated with the first Lord Harcourt, and was started in 1911 with private funds made available to form a collection of suitable objects. It soon succeeded in creating interest and attracting gifts and loans. King George $\mathrm{V}$ gave permission for the Museum to be housed in the State Apartments and other parts of Kensington Palace where the Museum was opened to the public in 1912. Kensington Palace was never intended to be more than a temporary home, and in 1913 Sir William Lever bought the lease of Stafford House and gave it to the Nation for the joint purposes of housing the London Museum and providing a setting for Government hospitality. The Trustees of the London Museum then placed their collections at the disposal of the Government for the term of the lease of Stafford House, and as long afterwards as the collection should continue to be exhibited there or in some other equally suitable building maintained by the Government. The Government accepted these offers, and undertook financial responsibility for maintaining the London Museum, and from that time onwards the Trustees, apart from some ex officio ones, were appointed by the Prime Minister. The Museum was accommodated in Lancaster House, as Stafford House was re-named, from 1913 until the Second World War when most of the collections had to be put into safe storage and Lancaster House began to be used for international conferences. In 1940 the original lease of the building expired and a new forty-twoyear lease was taken by the Ministry of Works from the Crown Estate. After the War the Government decided that the building would continue to be required for conferences and official hospitality and that another home would have to be found for the Museum. In 1949 King George VI gave consent for part of Kensington Palace again to be used by the Museum for a term of fifteen years from December 1950, and this term has been extended by Queen Elizabeth for a further five years to 1970.

Guildhall Museum was founded by order of the Court. of Common Council in 1826. The first contribution to the collections consisted of Roman and other antiquities found during the excavations of the foundations of the new post office in St. Martins le Grand. The original concept of the Museum was simply that of an adjunct to 